IZA DP No. 8360

The Performance Pay Premium:

How Big Is It and Does It Affect Wage Dispersion?

Alex Bryson

John Forth

Lucy Stokes

July 2014 


\title{
The Performance Pay Premium: How Big Is It and Does It Affect Wage Dispersion?
}

\author{
Alex Bryson \\ NIESR, CEP and IZA \\ John Forth \\ NIESR \\ Lucy Stokes \\ NIESR
}

Discussion Paper No. 8360
July 2014

IZA

P.O. Box 7240

53072 Bonn

Germany

Phone: +49-228-3894-0

Fax: +49-228-3894-180

E-mail: iza@iza.org

\begin{abstract}
Any opinions expressed here are those of the author(s) and not those of IZA. Research published in this series may include views on policy, but the institute itself takes no institutional policy positions. The IZA research network is committed to the IZA Guiding Principles of Research Integrity.

The Institute for the Study of Labor (IZA) in Bonn is a local and virtual international research center and a place of communication between science, politics and business. IZA is an independent nonprofit organization supported by Deutsche Post Foundation. The center is associated with the University of Bonn and offers a stimulating research environment through its international network, workshops and conferences, data service, project support, research visits and doctoral program. IZA engages in (i) original and internationally competitive research in all fields of labor economics, (ii) development of policy concepts, and (iii) dissemination of research results and concepts to the interested public.
\end{abstract}

IZA Discussion Papers often represent preliminary work and are circulated to encourage discussion. Citation of such a paper should account for its provisional character. A revised version may be available directly from the author. 


\title{
ABSTRACT \\ The Performance Pay Premium: How Big Is It and Does It Affect Wage Dispersion?*
}

\begin{abstract}
Using nationally representative linked employer-employee data we find one-quarter of employees in Britain are paid for performance. The log hourly wage gap between performance pay and fixed pay employees is .36 points. This falls to .15 log points after controlling for observable demographic, job and workplace characteristics. It falls still further to .10 log points when comparing "like" employees in the same workplace, indicating that performance pay contracts are used in higher paying workplaces. The premium rises markedly as one moves up the wage distribution: it is seven times higher at the 90th percentile than it is at the 10th percentile in the wage distribution (.42 log points compared to .06 log points).
\end{abstract}

JEL Classification: J33

Keywords: $\quad$ wages, wage inequality, performance pay, bonuses

Corresponding author:

Alex Bryson

National Institute of Economic and Social Research

2 Dean Trench Street

London, SW1P 3HE

United Kingdom

E-mail: a.bryson@niesr.ac.uk

\footnotetext{
* This work is funded by the Economic and Social Research Council, Grant Reference ES/I035846/1. We thank seminar participants at Durham Business School for comments. We are particularly grateful to Richard Harris for providing us with his TFP estimates. The authors acknowledges the Department of Business, Skills and Innovation, the Economic and Social Research Council, the Advisory, Conciliation and Arbitration Service and the National Institute of Economic and Social Research as the originators of the 2011 Workplace Employee Relations Survey data, and the Data Archive at the University of Essex as the distributor of the data. The paper includes analyses based on data from the Annual Survey of Hours and Earnings, produced by the Office for National Statistics (ONS) and supplied by the Secure Data Service at the UK Data Archive. The data are Crown Copyright and reproduced with the permission of the controller of HMSO and Queen's Printer for Scotland. The use of the data in this work does not imply the endorsement of ONS or the Secure Data Service at the UK Data Archive in relation to the interpretation or analysis of the data. This work uses research datasets which may not exactly reproduce National Statistics aggregates.
} 


\section{Introduction}

By rewarding output, performance pay offers employees the opportunity to earn more than they would under a fixed pay contract. But the incentive effect of performance pay isn't the only reason why one might observe a performance pay premium. It may compensate employees for the variability in earnings or increased effort that comes with performance pay contracts (Seiler, 1984), or reflect the sorting of more able employees into performance pay jobs. (Lazear, 1986, 2000).

Firm case studies find earnings rise on introducing performance pay as employees share in productivity growth (eg. Lazear, 2000). Wage gains are smaller but persist having accounted for workers' positive selection into performance pay (Pekkarinen and Riddell, 2008; Lemieux et al., 2009; Böckerman et al., 2013; Sommerfeld, 2012). However, the wage gains under performance pay may be over-stated if analysts fail to account for firm heterogeneity. Performance paying firms may be higher wage firms than those offering fixed wage contracts since they need to be able to recoup the costs of monitoring inherent in performance pay systems (Booth and Frank, 1999). Therefore failure to account for heterogeneity between performance pay firms and those using fixed pay contracts may upwardly bias estimates of the size of any performance pay premium. ${ }^{1}$

A small number of papers using linked employer-employee data indicate failure to account for employer effects does lead to an upward bias in estimates of the performance pay premium. In their paper for Finland's metal industry, Pekkarinen and Riddell (2008: 307) show that accounting for employee-firm matches accounts for about $40 \%$ of the performance pay premium. Similarly, in their paper for the United States Lemieux et al.

\footnotetext{
${ }^{1}$ An analogy can be drawn with the union wage premium literature. Bryson (2002) demonstrates that part of the wage premium usually attributed to union membership is actually due to unionised firms being high paying firms.
} 
(2009: 26) find the introduction of job-match fixed effects into a log average hourly earnings equation reduces the coefficient on receiving performance pay by around $40 \%$. For Britain Manning and Saidi (2010) find the performance pay premium falls by around half when accounting for workplace fixed effects. However their study is limited by the absence of worker-level data on the receipt of performance pay.

Ours is the first paper to examine links between performance pay and wages in Britain using linked employer-employee data that are representative of employees in all but the smallest workplaces and contain individual-level measures of performance pay. We contribute to the literature in three ways. First, we estimate the probability of employees being paid for performance and establish whether associations established in the literature still hold when one accounts for workplace fixed effects. Second we estimate the wage premium associated with performance pay and establish what happens to that premium once one accounts for fixed differences between workplaces that do and do not pay for performance. Third, we estimate counterfactual wage distributions to identify the effects of performance pay on the wage distribution in British workplaces.

The paper is organised in the following way. Section Two introduces the data. The following three sections focus on the three substantive areas under investigation. Each section presents the theoretical framework, previous studies, and our estimation approach before presenting our results. Section Three examines the incidence of performance pay. Section Four estimates the performance pay premium while Section Five examines the link between performance pay and wage dispersion. Section Six discusses the implications of the findings and draws some conclusions. 


\section{Data}

We analyse linked employer-employee data from the Workplace Employment Relations Survey 2011 (WERS). Appropriately weighted, it is a nationally representative survey of workplaces in Britain with 5 or more employees covering all sectors of the economy except agriculture and mining (van Wanrooy et al., 2013). The analysis exploits two elements of the survey. The first is the management interview, conducted face-toface with the most senior workplace manager responsible for employee relations. Interviews were conducted in 2,680 workplaces between March 2011 and June 2012 with a response rate of $46 \%$. The second element is the survey of employees, distributed in workplaces where a management interview was obtained. Self-completion questionnaires were distributed to a simple random sample of 25 employees (or all employees in workplaces with 5-24 employees) in the 2,170 workplaces where management permitted it. Of the 40,513 questionnaires distributed, 21,981 (54\%) usable ones were returned. ${ }^{2}$ Weights are provided with the survey data to correct for the sample design and any observable non-response biases.

The performance pay measures are taken from the employee questionnaire. Employees are asked "Which of the following do you receive in your job here...Payments based on your individual performance or output; payments based on the overall performance of a group or a team; payments based on the overall performance of your workplace or organisation (eg. profit-sharing scheme)". They are instructed to tick all that

\footnotetext{
${ }^{2}$ An additional 3,858 questionnaires were distributed at 247 workplaces where there were no employee questionnaires returned. We assume that these questionnaires were never distributed by the employer (van Wanrooy et al., 2013: 210) so they are not included in the figures in the text.
} 
apply. ${ }^{3}$ We can therefore distinguish between employees' receipt of performance pay arising from individual, team and organisational performance. These types of performance pay have different implications for the way employees are paid so that studies that are unable to make these distinctions may be conflating types of performance pay scheme, or else capturing just one of them, making it difficult to interpret results or to compare results across studies. ${ }^{4}$

The analyses of wage levels and wage dispersion have log gross hourly wages as the dependent variable. WERS does not collect continuous data on employees' wages; instead it asks employees to categorize their gross weekly earnings into one of 14 bands ranging from 'less than $£ 60$ per week/£3120 per year' through to “£1051 or more per week/£54601 per year”. ${ }^{5}$

To obtain a continuous measure of gross hourly earnings the convention is to take the mid-point of the respondent's earnings band and divide this by the survey's continuous measure of hours worked (which includes overtime) ${ }^{6}$ However the choice of the mid-point is somewhat arbitrary and, in addition, one must make an assumption about the likely earnings of those in the top category, which has no ceiling (the convention is to use an earnings figure that is 1.5 times the lower bound of this top category) . To avoid these arbitrary imputations, which may result in mismeasurement of both wage levels and

\footnotetext{
${ }^{3}$ The question also includes the following aspects of compensation: basic fixed/salary wage; extra payments for additional hours of work or overtime; contributions to a pension scheme.

${ }^{4}$ For a discussion of various types of performance pay schemes and analyses pointing to differences in the correlates of different types of scheme see Bryson et al. (2013).

${ }^{5}$ The wage is based on employee responses to the question: "How much do you get paid for your job here, before tax and other deductions are taken out? If your pay before tax changes from week to week because of overtime, or because you work different hours each week, think about what you earn on average." There is no explicit instruction to respondents as to whether to include performance payments and, since respondents may not have annual bonuses in mind when making the calculation, this earnings measure may understate earnings variance associated with performance pay.

${ }^{6}$ The question asks: 'How many hours do you usually work each week, including any overtime or extra hours?'
} 
wage dispersion, we adopt a new imputation procedure based on real wage data from the Annual Survey of Hours and Earnings (ASHE) ASHE is a random sample of 1 per cent of all employees in Britain based on the last two digits of their National Insurance number. The employer is required by law to provide the information which is based on payroll records; it is therefore highly reliable and there is no top-coding. ${ }^{7}$ For each employee in WERS, we impute a gross hourly wage by using ASHE to estimate the mean hourly wage of all employees within the hourly wage interval indicated by the WERS data.

Figure 1 compares imputed gross hourly earnings based on the conventional approach with those based on our new ASHE-based method. The correlation between the two measures is 0.99 , the chief difference in the distribution being the more bunched nature of earnings at the top of the earnings distribution when making the ASHEadjustment. In other words, wages are less dispersed under our procedure than under the conventional approach. In fact, our results are very similar whichever approach is taken. ${ }^{8}$

\section{[INSERT FIGURE 1]}

One source of potential omitted variables bias is heterogeneity in workplace productivity. This does not affect within-workplace estimates of the performance pay premium but, if the incidence of performance pay is positively correlated with being in a highly productive workplace, it may be this - rather than performance pay itself - which

\footnotetext{
${ }^{7}$ We use the ASHE measure of annual earnings, divided by hours worked in the reference period. The advantage of the annual earnings measure is that it includes all payments made to an employee over the year, including cash and bonus payments made in months other than April. Judging by Forth et al.'s (2013) analysis of bonus payments over the year, a focus solely on April wages would lead to a substantial underestimate of bonuses paid to employees. ASHE has no measure of annual hours worked.

${ }^{8}$ Results based solely on the WERS earnings data is available from the authors on request.
} 
accounts for the premium received by performance pay employees. To address this issue we link WERS to workplace total factor productivity (TFP) estimates based on analyses of the Annual Respondents Database (ARD). ${ }^{9}$ In sensitivity analyses we incorporate TFP into estimates of the incidence of performance pay and estimates of the performance pay wage premium.

\section{The Incidence of Performance Pay}

In Lemieux et al.'s (2009) theoretical model firms pay for performance when the efficiency returns to doing so outweigh the costs of monitoring worker performance. Monitoring is assumed to be absent in fixed wage jobs since they pay a wage which is constant irrespective of worker output. Consequently, whereas employer expectations about worker ability may influence their propensity to offer a job, neither worker ability nor effort are rewarded under fixed wage contracts. ${ }^{10}$ So fixed wage contracts are likely to be offered where monitoring costs are high or where aspects of the job make it difficult for workers to affect output. Employers are likely to pay for performance for one of two reasons. They will do so where they wish to incentivise effort. This is most likely to occur where job characteristics mean there is a high marginal productivity of effort, as in the case where employees have a high degree of job autonomy, and where one worker's productivity has a substantial impact on other workers, as in the case of complementarity between the productivity of non-managerial employees and those higher up the

\footnotetext{
${ }^{9}$ These estimates were kindly provided by Richard Harris. For details on how they were derived see Harris and Moffatt, 2011). The matching procedure results in 573 WERS-ARD matches for private sector workplaces. We have TFP estimates for the period 2009-2012. We take the most recent estimate as our measure of TFP.

${ }^{10}$ This is an over-simplification, of course, since firms often monitor fixed wage employees to ensure they meet minimum performance standards, and because firms promote those in career jobs based on performance (Prendergast, 1999; Bryson et al. 2011).
} 
managerial hierarchy. ${ }^{11}$ Firms will also incentivise effort where the costs of monitoring performance are lower, as in cases where team working leads to group incentives under which employees monitor their co-workers (Freeman et al., 2010), or where a union lowers monitoring costs by operating as a monitoring device for the employer by enforcing job standards, often in return for a group bonus (Barth et al., 2012).

The second reason for firms paying for performance is to attract more able workers by offering them the opportunity to earn a wage that better reflects their actual productivity. Here performance pay is used by firms to sort workers across jobs/employers by ability. This may be profitable for the firm even in the absence of incentive effects. It may be optimal for firms to attract the most able workers with performance pay where there is high variance in ability, notwithstanding the additional monitoring costs this incurs.

\section{1: Hypotheses}

We test five propositions emerging from Lemieux et al's (2009) model about the conditions under which performance pay is chosen over fixed pay

Hypothesis 1: the probability of being paid for performance rises with ability

From a worker perspective this is because wage returns are higher for more able employees under performance pay than they are under fixed wage contracts. From a firm perspective, the tighter link between worker ability and work effort under performance pay means the efficiency gains from performance pay grow with the conditional variance of ability. Empirical studies find observable proxies for human capital such as work histories (Böckerman et al., 2013) and education (Lemieux et al., 2009) are usually

\footnotetext{
${ }^{11}$ Rosen (1990) gives this as one reason for the prevalence of performance pay for senior executives.
} 
positively correlated with performance pay. ${ }^{12}$ We test the proposition that more able employees are more likely to receive performance pay by examining the role of academic qualifications.

Hypothesis 2: women are less likely than men to receive performance pay

In addition to the role of worker ability discussed above, employees may also be heterogeneous in ways that affect their preference for performance pay, for instance with respect to their risk preferences and their taste for competition (Cornelissen et al., 2010). Our data do not contain information on risk preferences, nor on the role of relative worker performance. However, we do have employees' gender. Laboratory studies indicate women avoid performance pay and tournaments due to gender differences in attitudes rather than differentials in ability (Dohmen and Falk, 2011; Niederle and Vesterlund, 2007). If women are more averse to competition or more risk-averse than men (Croson and Gneezy, 2009: 448), we might anticipate a negative association between being a woman and receipt of performance pay. On the other hand, if performance pay is set according to objective criteria, it may reduce managers' ability to discriminate on pay on grounds such as gender, in which case it is plausible that those groups who are potentially subject to discrimination will sort into performance pay jobs in order to limit opportunities to discriminate against them. Using the 2004 version of the survey we use, Manning and Saidi (2010) find no strong association between receipt of performance pay and gender. However, they had to rely on occupation-level variance in performance pay, whereas we exploit new WERS data on individual-level data receipt, so our performance pay measure is less prone to measurement error than theirs.

\footnotetext{
${ }^{12}$ Booth and Frank's (1999) analysis for Britain using the British Household Panel Survey is an exception.
} 
Hypothesis 3: the probability of being paid for performance rises in jobs where output is most sensitive to effort and/or ability

These jobs include managerial positions - since those higher up the firm hierarchy can play a bigger role in the overall productivity of the firm - and jobs in which the employee has a high degree of job autonomy. Gittleman and Pierce (2013: R9) present clear evidence of a positive association between an individual's position in the work hierarchy and receipt of performance pay in the United States. Earlier establishment-level analyses for Britain suggest only a modest positive association between the presence of group or organisational level performance pay and job autonomy (Bryson and Freeman, 2010: 214). It is possible that the association is weak due to measurement error arising from a lack of individual-level information on performance pay receipt. We overcome this measurement error problem in the analyses presented here. ${ }^{13}$

\section{Hypothesis 4: Unionisation is positively correlated with performance pay}

It is often assumed that unions' desire to standardise wages for jobs limits employers' ability to permit wages to vary with worker performance. However, one might anticipate a positive association between unionisation and performance pay for two reasons. First, as noted earlier, firms' monitoring costs may be lower where unions act as agents for the firm in enforcing effort levels (Barth et al., 2012), thus increasing employers' returns to performance pay once monitoring costs are factored in. The second is that, if performance pay is more efficient than fixed wages, it will generate a surplus which unions will be able to bargain over, thus making unions predisposed to performance pay (Booth and Frank, 1999). Using individual-level data from the British

\footnotetext{
${ }^{13}$ It is notable, however, that Dube and Freeman (2010) find strong positive associations between employees' decision making autonomy and performance pay in both individual-level and establishmentlevel analyses.
} 
Household Panel Survey Booth and Frank (1999) find a positive association between performance pay and unionisation. Analyses of establishment level data for Britain indicate that the association between union recognition for pay bargaining and performance pay varies with the type of performance pay scheme (Pendleton et al., 2009). Similarly, using individual-level panel data from the National Longitudinal Survey of Youth (NLSY) O'Halloran (2013) finds union membership and coverage are negatively correlated with bonus payments, stock options and profit-sharing, but positively associated with piece-rates. ${ }^{14}$ Ours is the first paper to exploit withinworkplace variance in union membership and union coverage to estimate the link between unionisation and individual employees' receipt of performance pay.

Hypothesis 5: larger organizations are more likely to pay for performance

If larger firms are better able to absorb the fixed costs associated with monitoring performance employees in those firms are more likely to receive performance pay. Evidence from establishment-level analyses for Britain identify a positive association between organisation size and pay linked to the performance of the team, workplace or organisation (including profit-related pay and share ownership schemes) but no correlation with pay based on individual performance (Pendleton et al., 2009). For the United States the direction of the relationship with establishment size varies with the definition of performance pay (Gittleman and Pierce, 2013: R9-R10).

\section{2: Estimation}

\footnotetext{
${ }^{14}$ In contrast, using establishment data for the United States, Gittleman and Pierce (2013: R9) find unionisation is negatively associated with performance pay, regardless of the way it is defined.
} 
We first present descriptive analyses of the incidence of performance pay among employees in Britain and then run multivariate models to identify factors that are independently correlated with performance pay. The main models we present identify any performance pay, but we also report on models run for different types of performance pay where performance is measured at individual, group/team or workplace/organisationlevel. We estimate these binary $(0,1)$ outcomes using linear estimation. Right-hand side variables include individuals' demographic and job characteristics and workplace characteristics. These models are supplemented by workplace fixed effects models where workplace dummies replace the observable workplace characteristics to identify the correlates of performance pay across employees within the same workplace having accounted for unobservable fixed characteristics of the workplace.

Many studies focus exclusively on performance pay in the private sector. However, there is growing interest in the use of performance pay among public sector employees. For this reason, and because we anticipate the correlates of performance payment in the public and private sectors may differ systematically, we run models for the whole economy and the private and public sectors separately.

Throughout, the estimation accounts for complex sample design. We apply survey weights to account for employees' probability of selection into the survey and to compensate for sample non-response bias, and when making statistical inferences we take account of the clustering of employees into workplaces (which are the primary sampling unit) and the probability of a workplace being sampled, which is based on stratifying variables relating to establishment size and industry. ${ }^{15}$

\footnotetext{
${ }^{15}$ For more on the sampling and survey methodology for WERS see Van Wanrooy (2013).
} 


\section{3: Results}

Almost one-quarter (23 per cent) of employees say they are paid for performance (Table 1), which is considerably lower than the estimate of 32 per cent provided by Manning and Saidi using their occupational level measure of performance pay. Of these around one-third (7 per cent of all employees) have some of their pay tied to performance via two or three performance pay mechanisms. The most common form of performance pay is that which ties employees' pay to their individual performance, followed by that tied to the performance of their workplace or organisation. Team or group-based performance pay is the least common form of performance pay in the economy. We know from other sources that performance pay constitutes a relatively small proportion of total pay for most employees (Bell and Van Reenen, 2013: 29) and that it accounts for quite a small percentage of firms' total wage bills in firms outside Finance (Forth et al., 2013). WERS does not contain information on the size of the performance payments made, but it does indicate that only 3 per cent of all employees - 13 per cent of those in receipt of some performance pay - say they only receive performance pay and do not receive a basic or fixed salary or wage.

\section{[INSERT TABLE 1]}

The incidence of performance pay is four-times higher in the private sector than the public sector (28 per cent compared with 7 per cent), a picture replicated when employers are asked to identify whether they run performance pay schemes at their 
workplace (van Wanrooy et al., 2013: 96). Individual performance pay was the dominant form of performance pay in the public sector. However much of this is accounted for by employees in Public Administration, some of whom may be reporting receipt of nonconsolidated bonuses in the wake of a pay freeze. ${ }^{16}$

Table 2 indicates that employees' highest academic qualification is positively correlated with the probability of being on a performance pay contract. This is consistent with the proposition in Hypothesis 1 that there is a positive link between ability and receipt of performance pay. However, qualifications are not strongly associated with performance pay in the public sector. Performance pay is not used to attract more able employees in the public sector or, if it is, more able employees are not taking up performance pay. This is not particularly surprising given the public sector's reliance on long-term career incentives for professional workers.

\section{[INSERT TABLE 2]}

In the private sector, the probability of being paid for performance rises monotonically with one's highest qualification until degree-level. In the absence of controls those with degree-level qualifications are about 25 per cent more likely than their unqualified counterparts to be on a performance pay contract (column 4). Over one-third of the raw correlation between performance pay and qualifiations is actually attributable to other demographic, job or workplace characteristics, though the pattern of coefficients

\footnotetext{
${ }^{16}$ The workplace-level incidence of performance pay in the public sector is 21 per cent in 2011. There has been some growth in pay attached to organizational performance which is due to the growth of financial participation schemes in the postal service, much of which has now been privatised (van Wanrooy et al., 2013: 96).
} 
is similar with controls (column 5). These patterns are found for all three types of performance pay, though the association with educational qualifications is strongest where performance is linked to workplace or organisational performance. ${ }^{17}$

The introduction of workplace fixed effects doubles the variance accounted for by the model (the r-squared rises from 0.21 to 0.46 between columns 5 and 6), confirming the importance of otherwise unobservable fixed workplace traits in explaining the incidence of performance pay. The association between performance pay and qualifications is attenuated still further with the introduction of workplace fixed effects and the effects are broadly flat among those with at least one A-level (column 6). The implication is that some of the selection of employees into performance pay by ability is sorting across workplaces. Even so, those with degree-level education are around 10 per cent more likely to be on performance pay contracts relative to "like" unqualified employees working in the same workplace.

Women are less likely to be subject to performance pay than men (Table 1). The raw female-male differential for the receipt of any performance pay is twice as large in the private sector as it is in the public sector (Table 3, columns 4 and 7). In the private sector the differential is halved to 5 percentage points with the introduction of individual, job and workplace controls, and it falls still further to 3 percentage points with the replacement of workplace characteristics by workplace fixed effects. These findings confirm the conjecture in $\underline{\text { Hypothesis } 2}$ that women are less likely to be on performance pay contracts than men. However, the differential is not particularly large, which might

\footnotetext{
${ }^{17}$ The results pertaining to individual, group/ and workplace/organisational performance are not presented in tabular form. They are available from the authors on request.
} 
explain why Manning and Saidi (2010) find no significant differential using occupational-level data which is more prone to measurement error.

\section{[INSERT TABLE 3]}

The situation is a little different in the public sector: although women are 5 percentage points less likely to be on a performance pay contract than observationally equivalent men, this coefficient is close to zero and is not significant once workplace fixed effects are introduced. This suggests the performance pay gender differential in the public sector is accounted for by differential sorting across workplaces: women and men in the same public sector workplace are equally likely to be on a performance pay contract.

Descriptive analyses suggest that a gender differential in the receipt of performance pay is apparent for all three types of performance pay (Table 1). However in multivariate analyses the gender differentials were similar for individual performance pay and pay based on workplace or organisational performance: they were absent in the case of team or group based performance. ${ }^{18}$ This suggests that the gender differential may not be driven by women's concerns about exposure to competition with colleagues since, if this were the case, one might have expected the differential to be greatest with respect to pay based on individual performance.

In accordance with Hypothesis 3 , being paid for performance is positively associated with being in a job where output is sensitive to the employee's ability or effort, as indicated by being in a managerial position and by the degree of control the employee

\footnotetext{
${ }^{18}$ These regressions are available from the authors on request.
} 
has in the job (Table 4). However, the association is only apparent among private sector employees, an indication that performance pay in the public sector is not used to incentivise those capable of increasing the output in their job. Managers in the private sector are roughly 12 per cent more likely than other employees to have their pay tied to performance, other things equal. The manager-non-manager differential is apparent for all three types of performance pay, but it is a little larger for contracts linking pay to workplace or organisational performance, as one might anticipate if managers are held responsible for the performance of those below them in the managerial hierarchy.

\section{[INSERT TABLE 4]}

The association with job control, while robust to the inclusion of demographic, job and workplace controls, is not statistically significant with the introduction of workplace fixed effects. This suggests that part of the association is attributable to unobservable workplace-level effects.

Contrary to Booth and Frank (1999) the association between performance pay and unionisation in the raw data is negative. With the introduction of controls, union coverage is negatively associated with performance pay in the private sector, while union membership is not significant. However, this coverage effect is no longer significant with the introduction of workplace fixed effects, suggesting the link to coverage is driven by unobservable workplace features influencing both coverage and performance pay. In the public sector neither coverage nor membership is associated with performance pay. Distinguishing between types of performance pay reveals negative associations between 
coverage and membership and pay linked to both individual and group performance. But, again, these effects are absent in the presence of workplace fixed effects. Neither the opportunity for rent capture by unionised workers, nor the potential agency role unions might perform in reducing the costs of monitoring performance are sufficient to induce a positive correlation. We can therefore refute the proposition in $\underline{\text { Hypothesis } 4}$ that performance pay will be positively correlated with unionisation.

In accordance with Hypothesis 5 the likelihood that an employee will be paid for performance tends to be higher in larger organisations - as indicated by a variable distinguishing single-establishment from multi-establishment organisations - and the number of employees employed at the workplace. However, the size and significance of these associations vary across the private and public sectors. In the private sector, employees in single-establishment organisations were 12 per cent less likely to be on a performance pay contract than "like" employees in multi-site organisations. The effect was smaller in the public sector (4 per cent), but still statistically significant. In both the private and public sectors the probability of being paid for performance rose sharply in the largest workplaces with at least 500 employees. Private sector employees working in these workplaces were 13 per cent more likely to be in receipt of performance pay than "like" employees in smaller workplaces, whereas there was no significant difference in performance pay incidence among workplaces below the 500 employee threshold. In the public sector the differential was 8 per cent. ${ }^{19}$

We reran the estimates above for the sub-set of private sector workplaces for which we have TFP estimates. None of the results above are sensitive to the inclusion of

\footnotetext{
${ }^{19}$ These effects were apparent for different types of performance pay, although the association with workplace size was not significant for group or team-based performance pay.
} 
TFP estimates for the workplace. TFP is positively and significantly correleated with individuals' receipt of performance pay, confirming the expectation that more productive organisations are more likely to pay for performance.

\section{The Performance Pay Premium}

\section{1: Hypotheses}

Having examined employees' propensity to be subject to performance-related pay, we now go on to test four hypotheses regarding links between performance pay and wages.

Hypothesis 6: employees are paid more in performance pay jobs than in fixed wage jobs. Part of this differential is an incentive effect, but much of it is due to sorting on ability and firm heterogeneity

We hypothesise that there will be a sizeable wage gap between performance pay and fixed rate jobs. However, this gap will partly reflect positive selection into performance pay jobs by more able employees. We are unable to account for unobservable differences between employees in the private and public sectors in our data. However, we can account for part of their human capital by controlling for their academic qualifications, tenure and age. We also try to partial out the incentive effect by conditioning on how hard employees say they work. If performance pay contracts are more likely to be offered by high wage firms for reasons noted above, the wage gap will fall still further having accounted for workplace fixed effects.

In their analysis of individual level surveys of British employees in the late 1990s and early 2000s McGovern et al. (2007: 172-186) estimate wage returns of between 5- 
$17 \%$ depending on the type of incentive and survey year. Using the 2004 Workplace Employment Relations Survey Manning and Saidi (2010) estimate a raw log hourly wage gap of .17 points between those on performance pay and fixed wage employees. This falls to .13 points with controls for personal characteristics and .05 when controlling for job characteristics. It falls still further to .025 points with the addition of workplace fixed effects, reflecting the importance of workplace fixed effects noted in the introduction for studies for other countries. However, as noted earlier, the performance premium is likely to have been understated by Manning and Saidi because of their inability to observe PRP at the individual level.

Hypothesis 7: the wage returns to performance pay are lower for women than they are for men

If women are averse to competition as discussed in Hypothesis 2 above, it may be that women who find themselves in performance pay jobs perform more poorly than men, in which case we might expect the wage returns to performance pay to be lower for women than for observationally equivalent men. This may be most apparent for individual performance pay where individuals are often in competition with one another for performance payments. ${ }^{20}$ However, in their analysis of the 2004 Workplace Employment Relations Survey Manning and Saidi (2010: 688-689) find the wage returns to performance pay are very similar for men and women.

Hypothesis 8: returns to skill are higher in performance pay jobs

\footnotetext{
${ }^{20}$ Bandiera et al. (2005) demonstrate attitudes towards competition affect worker performance under particular incentive schemes. They show employees are less productive when incentive schemes put workers in competition with one another compared to a piece rate scheme where the relative performance of co-workers is irrelevant.
} 
Following Lemieux et al. (2009: 28-30) we test the hypothesis that returns to skill are higher in performance pay jobs than they are in fixed pay jobs by interacting performance pay with qualifications, tenure and age ${ }^{21}$ in the earnings equation and by comparing the coefficients on these measures of human capital in separate earnings equations for performance pay and fixed pay jobs. When they do this, Lemieux et al. (2009: 28-30) confirm that returns to education and experience are larger in performance pay jobs than in non-performance pay jobs, whereas there is no difference in returns to tenure.

\section{Hypothesis 9: Unions raise the performance pay premium}

Unions will seek to extract some of the additional rents generated by performance pay (Booth and Frank, 1999). Thus, if workers have sufficient bargaining power, this should be apparent in a positive and statistically significant interaction between performance pay and union coverage/membership.

\section{2: Estimation}

The procedures used to estimate influences on employees' log hourly wages are similar to those used to establish the correlates of performance pay. Again, we use linear estimation and workplace fixed effects estimates. We focus on whole-economy estimates and estimates for private sector employees because the numbers of public sector employees subject to performance pay in our sample are low. A variety of robustness checks are undertaken including removal of observations at the top and bottom 1 percent

\footnotetext{
${ }^{21}$ Lemieux et al. (2009) use potential experience. We use age instead.
} 
of the earnings distribution and the inclusion of workplace TFP for a subset of private sector workplaces.

\section{3: Results}

Table 5 shows the association between being on a performance pay contract and $\log$ hourly wages. The raw wage gap between those on performance pay and those who are not is $0.36 \log$ points, rising to 0.44 in the private sector (columns 1 and 5). Differences in the human capital attributes of performance pay and fixed pay employees account for between one-fifth and one-quarter of this raw difference (19 per cent in the whole economy and 25 per cent in the private sector). The addition of all other (demographic, job and workplace) controls reduces the performance pay coefficient by nearly half again. The models in columns (3) and (7) account for well over half of all wage variance. With the introduction of workplace fixed effects the models account for 70 percent of the variance in employees' log hourly wages. The decline in the performance pay coefficient with the introduction of workplace fixed effects (shifting from column 3 to column 4 for the whole economy and column 6 to column 7 for the

private sector) confirms that performance pay is offered by workplaces that pay higher wages. Within workplaces those on performance pay contracts earn about 10 per cent more (0.1 log points) than their fixed wage counterparts.

[INSERT TABLE 5]

This performance pay premium is sizeable. For instance, it is roughly twice the size of the union membership wage premium estimated in the fixed effects model for the 
whole economy. ${ }^{22}$ The premium is considerably larger than Manning and Saidi's (2010) estimates, discussed earlier, which used the 2004 Workplace Employment Relations Survey. They rely on an occupation-level measure of the incidence of performance pay, which may have induced measurement error leading to a lower estimate.

It is possible that the premium attached to a performance pay job simply reflects being in a job which requires the worker to work harder than fixed pay jobs which pay wages for the time worked as opposed to output. To test this proposition we introduced an additional control variable identifying how strongly the employee agreed with the statement "My job requires that I work very hard". Although this is positively and significantly correlated with hourly earnings its introduction has no effect on the performance pay coefficient.

We add workplace TFP to the earnings model for the subset of private workplaces for which it is available. It is positively and significantly associated with earnings when entered alongside the performance pay indicator, but the association is no longer apparent when controls are added. The coefficient on performance pay and its significance are robust to the inclusion of TFP. ${ }^{23}$

Thus the conjectures in Hypothesis 6 are supported by the analysis. Those on performance pay earn more than those on fixed wages. Part of the difference is accounted for by higher human capital among performance pay employees. For example, an Oaxaca-Blinder decomposition of the log hourly wage gap between performance pay and non-performance pay employees in the private sector reveals that 5 percentage points of the 44 percentage point difference in log hourly wages between employees on

\footnotetext{
${ }^{22}$ The coefficient for union membership in the whole economy is 0.04 , t-stat $=3.50$.

${ }^{23}$ The model without controls is run on 3,476 private sector employees, falling to 3,400 when run with controls.
} 
performance pay and fixed wages can be accounted for observable human capital, as captured in individuals' qualifications, age and workplace tenure - this amounts to 19 per cent of the explained gap and 11 per cent of the total wage gap. Much of the rest of the explained gap of 26 percentage points is due to performance pay being more prevalent in higher-wage workplaces. But still a sizeable performance pay premium is apparent. Any association between performance pay and being in a job that requires the employee to work harder does not affect the size of the premium.

As noted earlier, some employees' pay is tied to performance at more than one level (eg. to the performance of a group and to individual performance). Although this is the case for a relatively small percentage of all employees - 7 per cent of employees across the economy and 9 per cent of those employed in the private sector - the performance pay premium is higher in these circumstances. This is even true within workplaces. For example, in the workplace fixed effects model equivalent to model (4) in Table 5 for the whole economy those on a contract tying pay to a single performance measure - individual, group/team or workplace/organization - receive a pay premium of roughly 0.08 log points relative to a "like" employee in the same workplace who is on fixed pay. This premium rises to 0.10 log points if the same individual was in receipt of performance pay for both group/team and workplace/organization performance, 0.13 log points if paid for individual and workplace/organizational performance, and 0.21 log points if paid for individual and group/team performance. In the private sector the premium for a single type of performance pay is around 0.10 log points, but it is higher for those paid under multiple performance pay schemes, the largest premium being 0.21 $\log$ points if paid for individual and group/team performance. There are various reasons 
why the performance pay premium could be higher for those paid under multiple schemes. For example, if these are the jobs with the greatest gearing of pay to performance they may attract the most able employees. Alternatively, those paid under multiple performance pay schemes may receive compensation for the additional risks to which they are exposed.

The raw wage gap between those paid for performance and those paid a fixed wage is significantly larger among men than it is among women (Table 6). The raw difference for employees across the whole economy is 1.5 times larger among men than it is among women (.38 compared with .25). However, the differential wage returns to performance pay between men and women disappear once we control for demographic, job and workplace characteristics: when this is done the returns to performance pay are almost identical across men and women (.13 log points versus .14). This is also the case within workplaces (.10 log points for men and women). The implication is that selection into performance pay jobs is more strongly correlated with wage enhancing attributes among men than it is among women. The story is similar in the private sector (Panel B of Table 6). Therefore there is no support for the contention, expressed in Hypothesis 7, that the returns to performance pay are lower for women. This finding echoes the earlier work by Manning and Saidi (2010), and suggests that, if women do have an underlying tendency to perform more poorly than men under performance pay (due to differences in tastes for competition and risk), there must also be positive selection into performance pay jobs by women along dimensions that are unobservable to us. We cannot discount this possibility, but we find no difference in the returns to performance pay after controlling for a rich set of observable characteristics 


\section{[INSERT TABLE 6]}

In Table 7 we interact the performance pay dummy with our three measures of human capital (highest academic qualification, years of tenure at the workplace, and age) entered as linear terms. In the whole economy models and the private sector models the interaction between performance pay and qualifications is positive and statistically significant and remains so with the introduction of controls. However, the coefficient drops to almost zero and is no longer statistically significant in the workplace fixed effects model. Similar findings are apparent if one allows the coefficients on all variables to differ across performance pay and non-performance pay employees by running separate regressions for the two sectors. Consequently, whilst there may appear to be higher returns to qualifications in the performance pay sector, these are in fact accounted for by highly qualified workers sorting into higher paying workplaces which are also performance pay workplaces. Thus, although there is prima facie support for the contention in Hypothesis 8 that returns to skill are higher in performance pay jobs, the effect is in fact generated by worker sorting across workplaces. It is not apparent among employees in the same workplace. Furthermore, the interaction between performance pay and workplace tenure - a rough proxy for the returns to firm-specific human capital - are never statistically significant. Age is a proxy for labour market experience. Its interaction with performance pay is positive and statistically significant in all whole economy models, including when we compare employees within the same workplace. However, 
the effect is only significant at a 90 per cent confidence interval in the private sector models once one controls for individual, job and workplace controls.

\section{[INSERT TABLE 7]}

Contrary to Hypothesis 9, the returns to performance pay appear to be higher in the absence of unions. The raw performance pay differential is twice as high in the uncovered sector as it is in the covered sector $(.41 \mathrm{log}$ points compared with $.23 \mathrm{log}$ points). However, the differential is not robust to the inclusion of controls. Rather, the performance pay premium is almost identical in the covered and uncovered sectors once one controls for compositional differences in employees, their jobs and workplace characteristics. It may be that union bargaining over the returns to performance pay is fairly ineffectual.

\section{Wage Dispersion and Performance Pay}

\section{1: Hypotheses}

In the third and final empirical part of the paper, we move on to examine the link between performance pay and wage dispersion.

Hypothesis 10: Wage dispersion will be greater in performance pay jobs, but the effect will be attenuated where employees are unionised

Lazear (1986; 2000) and Prendergast (1999) argue that performance pay generates higher wage dispersion than fixed rate pay due to the sorting of high ability workers into performance pay jobs - a labour market segmentation type argument - and because 
performance pay better reflects individuals' marginal product than do fixed wage schedules. Performance pay jobs provide opportunities for high ability workers to recoup returns to their ability in a way that is not possible with fixed wages, while the higher incidence of performance pay at the top end of the earnings distribution which characterises many studies for Britain (Bell and Van Reenen, 2010) the United States (Lemieux et al., 2009; Gittleman and Pierce, 2013) and other countries (eg. Sommerfeld, 2012 for Germany) also generates higher wage dispersion.

Although this proposition seems plausible, Manning and Saidi (2011) show that, while there is a wage premium attached to the receipt of performance pay, it had a negligible effect on wage dispersion in the 2004 version of our data. This may be because bonuses account for only a small proportion of total earnings for those outside the top decile of earners (Bell and Van Reenen: 2013, 10-11) or because Manning and Saidi are unable to reliably identify workers in receipt of performance pay.

We also test Barth et al.'s (2012) proposition that union coverage mitigates the effects of performance pay on wage dispersion due to unions' desire to standardise wages and link wage setting to job attributes, as opposed to individuals' ability. ${ }^{24}$ We test this proposition by examining the effects of performance pay on the wage dispersion of workplaces in the presence and absence of union members and collective bargaining coverage.

\section{3: Estimation}

\footnotetext{
${ }^{24}$ Unions continue to compress wages in Britain, performing what some have termed a "sword of justice" role (Bryson and Forth, 2010).
} 
Estimates of the relationship between performance pay and the wage distribution are based on a reweighting estimator originally deployed by DiNardo, Fortin and Lemieux (1996). The method constructs a counterfactual wage distribution which proxies the wage distribution that would obtain in the absence of performance pay in the economy. This is achieved by reweighting those sample members who are not in receipt of performance pay such that their observable characteristics closely resemble those of their performance pay counterparts. This in turn is achieved by running a probit estimate for the probability of being in receipt of performance pay and then using the predicted probabilities to reweight the non-performance pay employees in such a way as to give additional weight to those with high estimated probabilities of performance pay receipt. One can then recover the "effect" of performance pay at different parts of the wage distribution by comparing the actual distribution of wages among performance pay workers to the counterfactual distribution observed among the reweighted set of workers not in receipt of performance pay. This technique is identical to propensity score matching which is often used in the programme evaluation literature to recover the impact of treatment having balanced the treated and untreated samples on observable X's to recover differences in mean outcomes for the treated and counterfactual untreated. ${ }^{25}$ The difference, of course, is that the reweighting estimator is recovering counterfactual wages across the wage distribution, rather than simply mean outcomes. Comparisons of the actual wage distribution and the counterfactual wage distribution allow us to identify

\footnotetext{
${ }^{25}$ The technique deals with selection into treatment on observables and recovers the treatment-on-thetreated parameter for performance pay across the wage distribution. It is unable to generate estimates which account for unobservable differences across treated and untreated observations. The identifying assumption is that error terms are uncorrelated with treatment status having conditioned on observables, such that outcomes are independent of treatment status conditional on observables (the conditional independence assumption or CIA). For further discussion see DiNardo et al. (1996) and DiNardo (2002).
} 
that part of the wage gap between performance pay and non-performance pay employees that is attributable to performance pay, as opposed to differences in their observable characteristics. As DiNardo (2002) notes, at the mean, this estimate is identical to that obtained using the Oaxaca-Blinder wage decomposition method.

\section{4: Results}

Figure 2 compares the log hourly earnings of performance pay and nonperformance pay employees across the wage distribution. The solid line is the raw difference between those paid for performance and those on fixed wages at each point in the log hourly wage distribution. The raw gap is rising as one moves up the wage distribution, from around $.1 \log$ points at the 5th percentile of the wage distribution, to .38 at the median, to around $.6 \log$ points by the 80 th percentile in the wage distribution. The gap then falls a little before it starts rising again at the very top of the distribution.

\section{[INSERT FIGURE 2]}

The dotted line represents the counterfactual performance pay gap based on a comparison of the wages of the performance pay employees with those of fixed wage employees having reweighted the observable characteristics of the fixed wage employees so that they are observationally equivalent to the attributes of the performance pay employees. The counterfactual gap also rises as one moves up the wage distribution in a manner similar to the raw gap. However, the counterfactual gap lies below the raw gap throughout the wage distribution, confirming that there is positive selection into performance pay on observable characteristics at all points in the distribution. In the 
bottom quartile of the wage distribution a little over half the raw gap is accounted for by differences between performance pay and non-performance pay employees in terms of their demographic, job and workplace attributes. But the percentage of the gap accounted for by observable differences diminishes further up the wage distribution. At the median point in the wage distribution .16 of the .38 log point raw differential (42 percent) is due to observational differences between performance pay and fixed pay employees. At the 90th percentile only $.17 \log$ points of the .59 log point wage gap (29 per cent) is due to compositional differences between performance pay and fixed pay employees. As the size of the unexplained gap rises further up the wage distribution (from .06 log points at the $10^{\text {th }}$ percentile to $.42 \log$ points at the $90^{\text {th }}$ percentile), the implication is that performance pay does widen wage differentials in Britain, as it has been shown to do in countries such as the US and Germany, and it does so to quite a considerable extent. ${ }^{26}$ The findings therefore confirm Hypothesis 10.

There is also support for the second part of Hypothesis 10 which suggested that the ability of performance pay to increase wage dispersion will be attenuated in the covered sector. This is apparent when comparing Figures 3 and 4 which present results for the whole economy split according to the coverage status of employees. Although the performance pay premium rises moving up the wage distribution in the covered sector, the slope is less steep than in the uncovered sector. This finding, which explains why Hypothesis 9 was not supported, is consistent with the proposition that union coverage acts as a "break" on wage inequality induced by performance pay.

In their estimates of the effects of performance pay on the wage distribution Lemieux et al. (2009) adopt a different approach to DiNardo et al. (2002). Instead of

\footnotetext{
${ }^{26}$ Results are similar when estimated for the private sector only.
} 
reweighting the fixed wage employees so that they resemble the performance pay employees, they reweight them such that the distribution of their observable traits reflects the distribution across the whole sample. The intuition here is that if one were to ban performance pay the distribution of worker traits in the population would remain largely unchanged since there would be no very large supply shock to the economy due to employees responding through hours changes or participation decisions as a result of the end of performance pay. Of course, the raw gap between the pay of performance pay and fixed pay employees is the same as in Figure 2. What is different is the counterfactual performance pay gap. It is close to zero in the bottom half of the wage distribution, but then begins to rise so that it is $.08 \log$ points at the 75 th percentile, . 19 log points at the 95 percentile and .28 log points at the 99th percentile. The impact of performance pay on the wage distribution is smaller when one adopts this approach to reweighting the fixed pay employees when compared to the reweighting estimator used by DiNardo et al. (1996). This is because this alternative approach takes account of the fact that performance pay employees only account for a minority of all employees in the economy and, as such, their impact on the overall wage distribution is necessarily smaller than if one simply compares their wages to those of fixed pay employees having reweighted for observational differences.

[INSERT FIGURES 3 AND 4]

\section{Conclusions}


Using nationally representative linked employer-employee data we find onequarter of employees in Britain are paid for performance. Most of our hypotheses regarding the correlates of performance pay were supported empirically: those on performance pay contracts are more highly qualified and possess wage-enhancing attributes; they work in higher paying workplaces and for larger organisations; and they perform jobs where output is more sensitive to their performance. However, contrary to expectations, being on a performance pay contract was not correlated with union coverage status. We also showed, contrary to earlier research for Britain, that women are significantly less likely to be on performance pay contracts than men, even within the same occupation in the same workplace. However the differences are not large.

The log wage gap between performance pay and fixed pay employees is .36 points. This falls to .15 log points controlling for demographic, job and workplace characteristics. It falls still further to .10 log points when comparing "like" employees in the same workplace, indicating that performance pay contracts are used in higher paying workplaces.

The premium rises markedly as one moves up the wage distribution: it is seven times higher at the 90th percentile than it is at the 10th percentile in the wage distribution (.42 log points compared to .06 log points). This, coupled with the higher incidence of performance pay among those with wage-enhancing attributes, means performance pay contributes substantially to higher wage dispersion in Britain. However its overall effect on the wage distribution is less marked than it might have been due to the relatively low proportion of employees on performance pay contracts in Britain. 
We confirmed expectations that returns to skill are higher in performance pay jobs than they are in fixed wage jobs. However, contrary to expectations, wage returns to performance pay did not differ by gender. We also found that union covered employees received a lower performance pay premium than uncovered employees, especially in the top half of the wage distribution, such that union coverage attenuated the effects performance pay had on wage inequality induced by performance pay.

With so much of the research on performance pay based on insider econometric case studies or laboratory experiments knowledge regarding the incidence and operation of performance pay across the economy remains limited. With government keen to expand the use of performance pay in the public sector it is timely for analysts to start to fill this gap. We have begun to see in this paper that performance pay is very different in the public sector compared with the private sector. For instance, it is not targeted on those whose output is most sensitive to their performance. Nor does there appear to be selection into performance pay in the public sector based on observable ability traits. Understanding what performance pay is in the public sector and how it should be understood is just one of many issues facing economists in future work. 


\section{References}

Atkinson, A. Piketty, T. and Saez, E. (2011) "Top Incomes in the Long Run of History”, Journal of Economic Literature, 49:1, 3-71

Autor, D. H., Dorn, D. and Hanson, G. H. (2013) "Untangling Trade and Technology: Evidence from Local Labour Markets", mimeo

Autor, D. H., Katz, L. F. and Kearney, M. S. (2008) "Trends in US Wage Inequality: Revising the Revisionists", The Review of Economics and Statistics, 90, 2: 300323

Bandiera, O., Barankay, I. and Rasul, I. (2005) "Social Preferences and the Response to Incentives: Evidence from Personnel Data", The Quarterly Journal of Economics, 917-962

Bandiera, O., Barankay, I. and Rasul, I. (2007) "Incentives for Managements and Inequality Among Workers: Evidence from a firm-level experiment” The Quarterly Journal of Economics, 122(2): 729-773

Barth, E., Bratsberg, B., Haegeland, T. and Raaum, O. (2012) "Performance Pay, Union Bargaining and Within-firm Wage Inequality", Oxford Bulletin of Economics and Statistics, 74, 3: 327-362

Bell, B. and Van Reenen, J. (2010) "Bankers and Extreme Wage Inequality in the UK", Centre for Economic Performance Special Paper No. 21 (2013) "Bankers and their Bonuses", CEP Occasional Paper No. 35

Bell, B. and Van Reenen, J. (2011) "Firm Performance and Wages: Evidence from Across the Corporate Hierarchy", CEP Discussion Paper No. 1088 
Bryson, A. and Freeman, R. (2010) 'How does shared capitalism affect economic performance in the UK?', Chapter 6 in D. Kruse, R. Freeman and J. Blasi (eds.) Shared Capitalism at Work: Employee Ownership, Profit and Gain Sharing, and Broad-based Stock Options, pp. 201-224, University of Chicago Press

Böckerman, P., Bryson, A. and Ilmakunnas, P. (2013) 'Does High Involvement Management Lead to Higher Pay?', Journal of the Royal Statistical Society Series A, 176, 4: 861-885

Booth, A. L. and Frank, J. (1999) "Earnings, Productivity and Performance-related Pay", Journal of Labor Economics, 17, 3: 447-463

Brown, C. (1992) "Wage Levels and Method of Pay,” RAND Journal of Economics 23, 366-375

Bryson, A. (2002) The Union Membership Wage Premium: An Analysis Using Propensity Score Matching, Centre for Economic Performance Discussion Paper No. 530, London School of Economics

Bryson, A., Barth, E. and Dale-Olsen, H. (2012) “Do Higher Wages Come at a Price?”, Journal of Economic Psychology, 33, 1: 251-263

Bryson, A. Buraimo, B. and Simmons, R. (2011) 'Do Salaries Improve Worker Performance?', Labour Economics, 18, 4: 424-433

Bryson, A. and Forth, J. (2011) 'Trade Unions', Chapter 17 in P. Gregg and J. Wadsworth (eds.) The Labour Market in Winter: the State of Working Britain, pp.255-271, Oxford University Press, Oxford

Bryson, A., Freeman, R., Lucifora, C., Pellizzari, M and Perotin, V. (2013) "Paying for Performance: Incentive Pay Schemes and Employees' Financial Participation", in 
T. Boeri, C. Lucifora and K. J. Murphy (eds.) Executive Remuneration and Employee Performance-related Pay: A Transatlantic Perspective, Oxford University Press

Card, D., Lemieux, T. and Riddell, W. C. (2004) "Unions and Wage Inequality", Journal of Labor Research, 25: 519-559

Cornelissen, T., Heywood, J. and Jirhahn, U. (2010) "Performance Pay, Risk Attitudes and Job Satisfaction", Labour Economics, 18, 2: 229-239

Croson, R. and Gneezy, U. (2009) "Gender Differences in Preferences", Journal of Economic Literature, 47, 2: 448-474

DiNardo, J. (2002) "Propensity Score Reweighting and Changes in Wage Distributions", University of Michigan mimeo

DiNardo, J., Fortin, N. and Lemieux, T. (1996) "Labor Market Institutions and The Distribution of Wages, 1973-1993: A Semi-Parametric Approach," Econometrica, 64 (5), 1001-1045

Dohmen, T. and Falk, A. (2011) "Performance pay and multidimensional sorting: Productivity, Preferences and Gender", American Economic Review, 101(2): 55690

Dube, A. and Freeman, R. B. (2010), "Complementarity of Shared Compensation and Decision Making Systems: Evidence from the American Labor Market". In D. L. Kruse, R. B. Freeman and J. R. Blasi (eds.), Shared Capitalism at Work: Employee Ownership, Profit and Gain Sharing and Broad-based Stock Options, University of Chicago Press 
Dustmann, C., Ludsteck, J. and Schonberg, U. (2009) "Revisiting the German Wage Structure", The Quarterly Journal of Economics, 124, 2: 843-881

Forth, J., Bryson, A. and Stokes, L. (2013) "Are Firms Paying More For Performance?", NIESR Discussion Paper No. 423

Freeman, R. and Kleiner, M. (2005), "The Last American Shoe Manufacturers: Decreasing Productivity and Increasing Profits in the Shift from Piece Rates to Continuous Flow Production,” Industrial Relations, 44(2): 307-330

Freeman, R. B., Kruse, D. L. and Blasi, J. R. (2010) 'Worker Responses to Shirking Under Shared Capitalism', Chapter 2 in D. Kruse, R. Freeman and J. Blasi (eds.) Shared Capitalism at Work: Employee Ownership, Profit and Gain Sharing, and Broad-based Stock Options, pp. 77-104, University of Chicago Press

Gabaix, X. and Landier, A. (2008). 'Why has CEO pay increased so much?', The Quarterly Journal of Economics, vol. 121(1), pp. 49-100

Gittleman, M. and Pierce, B. (2013) "How Prevalent is Performance-Related Pay in the United States? Current Incidence and Recent Trends", National Institute Economic Review, 226: R4-R16

(2012) "Pay for Performance and Compensation Inequality: Evidence from the ECEC”, mimeo, Bureau of Labor Statistics

Green, C. P. and Heywood, J. S. (2012) "Don't Forget the Gravy! Are Bonuses and Time Rates Complements", mimeo

Gregg, P. and Machin, S. J. (2012) What a drag: the chilling impact of unemployment on real wages, The Resolution Foundation 
Harris, R. and Moffatt, J. (2011) "Plant-level Determinants of Total Factor Productivity in Great Britain, 1997-2006", SERC Discussion Paper No. 64, Spatial Economics Research Centre, London

Kaplan, S. N. (2012). 'Executive compensation and corporate governance in the US: perceptions, facts and challenges’, NBER Working Paper No.18395

Kruse, D. L., Blasi, J. R., and Park, R. (2010), 'Shared Capitalism in the US Economy: Prevalence, Characteristics and Employee Views of Financial Participation in Enterprises'. In D. L. Kruse, R. B. Freeman and J. R. Blasi (eds.), Shared Capitalism at Work: Employee Ownership, Profit and Gain Sharing and Broadbased Stock Options, University of Chicago Press

Lazear, E. (1986) “Salaries and piece rates” Journal of Business 59, 405-31. (2000) "Performance pay and productivity", American Economic Review, 90, 1346-1361.

Lemieux, T., MacLeod, W. B., Parent, D. (2009) "Performance Pay and Wage Inequality" Quarterly Journal of Economics, 124 (1): 1-49 (2012) "Performance Pay and the Autocovariance Structure of Earnings and Hours", mimeo

Manning, A. and Saidi, F. (2010) "Understanding the Gender Pay Gap: What's Competition Got to Do with It?", Industrial and Labor Relations Review, 63, 4: 681-698

McGovern, P., Hill, S., Mills, C. and White, M. (2007) Market, Class and Employment, Oxford University Press 
Niederle, M. and Vesterlund, L. (2007) "Do Women Shy Away from Competition?", The Quarterly Journal of Economics, 122, 3: 1067-1101

O'Halloran, P. (2013) "Union coverage, membership and performance-related pay: are piece rates different?", National Institute Economic Review No. 226: R30-R41

Office for National Statistics (2009) Summary Quality Report for the Annual Survey of Hours and Earnings, Newport: ONS

Papps, K. L., Bryson, A. and Gomez, R. (2011) 'Heterogeneous Worker Ability and Team-based Production: Evidence from Major League Baseball, 1920-2009', Labour Economics, 18, 3: 310-319

Pekkarinen, T. and Riddell, C. (2008) 'Performance Pay and Earnings: Evidence from Personnel Records' Industrial and Labor Relations Review 61, 297-319

Pendleton, A., Whitfield, K. and Bryson, A. (2009) 'The changing use of contingent pay in the modern British workplace', Chapter 11 in W. Brown, A. Bryson, J. Forth and K. Whitfield (eds.) The Evolution of the Modern Workplace, pp. 256-284, Cambridge University Press

Prendergast, C. (1999) 'The provision of incentives in firms' Journal of Economic Literature, 37, 1: $7-63$

Prendergast, C. (2000), “What Trade-Off of Risk and Incentives?”, American Economic Review, Vol. 90(2), pp. 421-425. (2002a), "The Tenuous Trade-off between Risk and Incentives", Journal of Political Economy, Vol. 110(5), pp. 1071-1102. (2002b), “Uncertainty and Incentives”, Journal of Political Economy, Vol. 20(2), pp. S115-S137. 
Rosen, S. (1990) 'Contracts and the market for executives', NBER Working Paper No. 3542

Shearer, B. (2004) "Piece rates, fixed wages and incentive effects: evidence from a field experiment", Review of Economic Studies 71, 514-534.

Seiler, E. (1984) "Piece rate vs. time rate: the effect of incentives on earnings", The Review of Economics and Statistics, 66: 363-376

Sommerfeld, K. (2012) "Higher and higher? Performance pay and wage inequality in Germany", mimeo

van Wanrooy, B., Bewley, H., Bryson, A., Forth, J., Freeth, S., Stokes, L. and Wood, S. (2013) Employment Relations in the Shadow of Recession: Findings from the 2011 Workplace Employment Relations Stud, Palgrave Macmillan 
Table 1: Incidence of Performance Pay (PP), column percentages

\begin{tabular}{|c|c|c|c|c|c|c|c|c|c|}
\hline & \multicolumn{3}{|c|}{ Private Sector } & \multicolumn{3}{|c|}{ Public Sector } & \multicolumn{3}{|c|}{ Whole Economy } \\
\hline & Men & Women & All & Men & Women & All & Men & Women & All \\
\hline Type of PP: & & & & & & & & & \\
\hline Any & 33 & 23 & 28 & 10 & 6 & 7 & 28 & 18 & 23 \\
\hline Individual & 18 & 12 & 15 & 6 & 5 & 5 & 16 & 10 & 13 \\
\hline Group/Team & 11 & 8 & 9 & 3 & 1 & 2 & 9 & 6 & 8 \\
\hline Workplace/Organisation & 18 & 11 & 15 & 3 & $*$ & 1 & 15 & 8 & 11 \\
\hline Number of PP schemes: & & & & & & & & & \\
\hline 0 & 67 & 77 & 72 & 90 & 94 & 93 & 72 & 82 & 77 \\
\hline 1 & 22 & 17 & 20 & 9 & 5 & 7 & 19 & 13 & 16 \\
\hline 2 & 7 & 5 & 6 & 1 & $*$ & 1 & 6 & 3 & 5 \\
\hline 3 & 4 & 2 & 3 & * & $*$ & $*$ & 3 & 1 & 2 \\
\hline Mix of PP: & & & & & & & & & \\
\hline None & 67 & 77 & 72 & 90 & 94 & 93 & 72 & 82 & 77 \\
\hline Individual only & 8 & 7 & 8 & 5 & 5 & 5 & 8 & 6 & 7 \\
\hline Group/team only & 4 & 4 & 4 & 2 & $*$ & 1 & 3 & 3 & 3 \\
\hline Workplace/org only & 10 & 6 & 8 & 2 & * & 1 & 8 & 4 & 6 \\
\hline Ind+Group & 2 & 2 & 2 & * & $*$ & $*$ & 2 & 1 & 2 \\
\hline Ind+WP/Org & 4 & 2 & 3 & * & * & * & 3 & 1 & 2 \\
\hline Group+WP/Org & 1 & * & 1 & 1 & * & * & 1 & 1 & 1 \\
\hline All three & 4 & 2 & 3 & * & $*$ & * & 3 & 1 & 2 \\
\hline
\end{tabular}

Notes: (1) Whole sample unweighted $\mathrm{N}=20,556$. Of these 12,691 are private sector employees, 7,825 are public sector employees. They are located at

1,919 workplaces. 146 observations are lost when splitting by gender. (2) * means $<1 \%$ 


\section{Table 2: Highest Educational Qualifications and Receipt of Performance Pay}

Whole Economy

\begin{tabular}{|c|c|c|c|c|c|c|c|c|c|c|c|c|c|c|c|c|c|}
\hline & \multicolumn{6}{|c|}{ Whole Economy } & \multicolumn{6}{|c|}{ Private sector } & \multicolumn{5}{|c|}{ Public Sector } \\
\hline & (1) & & (2) & & (3) & & (4) & & (5) & & (6) & & (7) & & (8) & & (9) \\
\hline & Raw & & Controls & & $\mathrm{FE}$ & & Raw & & Controls & & FE & & Raw & & Controls & & FE \\
\hline Other & $\begin{array}{l}0.04 \\
(1.78)\end{array}$ & * & $\begin{array}{l}0.02 \\
(0.98)\end{array}$ & & $\begin{array}{l}-0.01 \\
(-.32)\end{array}$ & & $\begin{array}{l}0.06 \\
(1.88)\end{array}$ & $*$ & $\begin{array}{l}0.03 \\
(1.12)\end{array}$ & & $\begin{array}{l}0 \\
(-.07)\end{array}$ & & $\begin{array}{l}-0.01 \\
(-.33)\end{array}$ & & $\begin{array}{l}-0.01 \\
(-0.52)\end{array}$ & & $\begin{array}{l}-0.02 \\
(-.94)\end{array}$ \\
\hline CSE & $\begin{array}{l}0.05 \\
(3.03)\end{array}$ & $* * *$ & $\begin{array}{l}0.03 \\
(1.66)\end{array}$ & $*$ & $\begin{array}{l}0.01 \\
(0.72)\end{array}$ & & $\begin{array}{l}0.06 \\
(2.76)\end{array}$ & $* * *$ & $\begin{array}{l}0.04 \\
(1.67)\end{array}$ & $*$ & $\begin{array}{l}0.02 \\
(0.70)\end{array}$ & & $\begin{array}{l}0.03 \\
(1.45)\end{array}$ & & $\begin{array}{l}0.02 \\
(1.15)\end{array}$ & & $\begin{array}{l}0.01 \\
(0.59)\end{array}$ \\
\hline O level & $\begin{array}{l}0.09 \\
(6.17)\end{array}$ & $* * *$ & $\begin{array}{l}0.05 \\
(3.71)\end{array}$ & $* * *$ & $\begin{array}{l}0.04 \\
(3.35)\end{array}$ & $* * *$ & $\begin{array}{l}0.12 \\
(6.40)\end{array}$ & $* * *$ & $\begin{array}{l}0.07 \\
(3.83)\end{array}$ & $* * *$ & $\begin{array}{l}0.06 \\
(3.52)\end{array}$ & $* * *$ & $\begin{array}{l}0.03 \\
(2.15)\end{array}$ & $* *$ & $\begin{array}{l}0.03 \\
(1.72)\end{array}$ & $*$ & $\begin{array}{l}0.01 \\
(0.35)\end{array}$ \\
\hline $1 \mathrm{~A}$ & & & & & & & & & & & & & & & & & \\
\hline level & $\begin{array}{l}0.09 \\
(3.83)\end{array}$ & $* * *$ & $\begin{array}{l}0.08 \\
(3.39)\end{array}$ & $* * *$ & $\begin{array}{l}0.07 \\
(3.36)\end{array}$ & $* * *$ & $\begin{array}{l}0.13 \\
(3.88)\end{array}$ & $* * *$ & $\begin{array}{l}0.09 \\
(2.96)\end{array}$ & $* * *$ & $\begin{array}{l}0.08 \\
(3.16)\end{array}$ & $* * *$ & $\begin{array}{l}0.05 \\
(2.10)\end{array}$ & $* *$ & $\begin{array}{l}0.05 \\
(1.80)\end{array}$ & $*$ & $\begin{array}{l}0.02 \\
(0.63)\end{array}$ \\
\hline $2+A$ & & & & & & & & & & & & & & & & & \\
\hline levels & $\begin{array}{l}0.12 \\
(5.97)\end{array}$ & $* * *$ & $\begin{array}{l}0.08 \\
(4.00)\end{array}$ & $* * *$ & $\begin{array}{l}0.07 \\
(3.66)\end{array}$ & $* * *$ & $\begin{array}{l}0.16 \\
(6.13)\end{array}$ & $* * *$ & $\begin{array}{l}0.1 \\
(3.97)\end{array}$ & $* * *$ & $\begin{array}{l}0.08 \\
(3.57)\end{array}$ & $* * *$ & $\begin{array}{l}0.04 \\
(2.03)\end{array}$ & $* *$ & $\begin{array}{l}0.04 \\
(1.77)\end{array}$ & * & $\begin{array}{l}0.02 \\
(0.97)\end{array}$ \\
\hline Degree & $\begin{array}{l}0.18 \\
(9.04)\end{array}$ & $* * *$ & $\begin{array}{l}0.11 \\
(6.23)\end{array}$ & $* * *$ & $\begin{array}{l}0.07 \\
(4.36)\end{array}$ & $* * *$ & $\begin{array}{l}0.26 \\
(10.64)\end{array}$ & $* * *$ & $\begin{array}{l}0.15 \\
(6.60)\end{array}$ & $* * *$ & $\begin{array}{l}0.1 \\
(4.79)\end{array}$ & $* * *$ & $\begin{array}{l}0 \\
(0.06)\end{array}$ & & $\begin{array}{l}0.01 \\
(0.43)\end{array}$ & & $\begin{array}{l}0 \\
(0.08)\end{array}$ \\
\hline $\begin{array}{l}\text { Further } \\
\text { degree }\end{array}$ & $\begin{array}{l}0.16 \\
(4.68)\end{array}$ & $* * *$ & $\begin{array}{l}0.11 \\
(4.32)\end{array}$ & $* * *$ & $\begin{array}{l}0.07 \\
(3.31)\end{array}$ & $* * *$ & $\begin{array}{l}0.23 \\
(5.47)\end{array}$ & $* * *$ & $\begin{array}{l}0.14 \\
(4.40)\end{array}$ & $* * *$ & $\begin{array}{l}0.09 \\
(3.44)\end{array}$ & $* * *$ & $\begin{array}{l}0.01 \\
(0.56)\end{array}$ & & $\begin{array}{l}0.02 \\
(0.65)\end{array}$ & & $\begin{array}{l}0.02 \\
(0.67)\end{array}$ \\
\hline$r 2$ & 0.02 & & 0.21 & & 0.47 & & 0.04 & & 0.21 & & 0.46 & & 0 & & 0.04 & & 0.31 \\
\hline$N$ & 18103 & & 17717 & & 17717 & & 11172 & & 10918 & & 10918 & & 6931 & & 6799 & & 6799 \\
\hline
\end{tabular}

Notes: (1) Reference for qualifications: no qualifications (2) Linear estimation. FE=workplace fixed effects (3) Controls are: female; age (6 dummies); white; disability; married/living as married; any dependent children; union member; covered by collective bargaining; occupation (9 dummies); usual hours worked (5 dummies); workplace tenure (5 dummies); contract type (3 dummies); job autonomy scale; industry (13 dummies); $N$ employees at workplace ( 6 dummies); single-establishment organisation; region (11 dummies). Workplace-level controls are replaced by workplace fixed effects in columns (3), (6) and (9) (4) t-stats in parentheses *=sig at $90 \% \mathrm{Cl}$; **=sig at $95 \% \mathrm{Cl} ; * * *=\operatorname{sig}$ at $99 \% \mathrm{Cl}$. 
Table 3: Gender and Receipt of Performance Pay Whole Economy

\begin{tabular}{|c|c|c|c|c|c|c|c|c|c|c|c|c|c|c|c|c|c|}
\hline & & & & & & & & & & & & & & & & & \\
\hline & & & (2) & & (3) & & (4) & & (5) & & (6) & & (7) & & (8) & & (9) \\
\hline & (1) Raw & & Controls & & $\mathrm{FE}$ & & Raw & & Controls & & $\mathrm{FE}$ & & Raw & & Controls & & $\mathrm{FE}$ \\
\hline Female & -0.11 & $* * *$ & -0.03 & $* * *$ & -0.03 & $* *$ & -0.10 & $* * *$ & -0.04 & $* *$ & -0.03 & $* *$ & -0.05 & $* * *$ & -0.05 & $* * *$ & -0.01 \\
\hline & $(-8.63)$ & & $(-2.96)$ & & $(-.34)$ & & $(-.31)$ & & $(-2.43)$ & & $(-.00)$ & & $(-.88)$ & & $(-3.39)$ & & (.55) \\
\hline r2 & 0.02 & & 0.21 & & 0.47 & & 0.01 & & 0.21 & & 0.46 & & 0.01 & & 0.04 & & 0.31 \\
\hline$N$ & 18103 & & 17717 & & 17717 & & 11172 & & 10918 & & 10918 & & 6931 & & 6799 & & 6799 \\
\hline
\end{tabular}


Table 4: Performance Pay Where Output is Sensitive to Performance

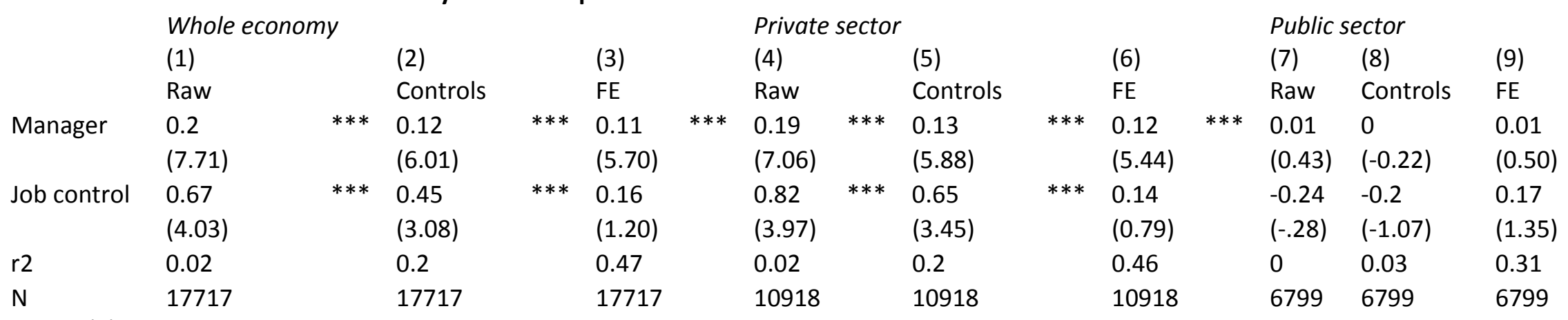

Notes: (1) the model is identical to those in Tables 2 and 3, but it replaces the 9 occupation dummies with a single dummy distinguishing managerial from non-managerial employees. (2) The job control scale is an additive scale ranging from zero (lowest control) to 15 (highest control). The scale is composed of responses to 5 questions asking employees how much influence they had over the tasks they do in their job, the pace at which they work, the order in which they carry out their tasks, and the time they start or finish their working day. The four-point response scale runs from "none" (zero) to "a great deal" (three). Coefficients have been divided by 100. (3) see notes to Table 2 for other details 
Table 5: Log Hourly Wages and Any Performance Pay

\begin{tabular}{|c|c|c|c|c|c|c|c|c|c|c|c|c|c|c|c|c|}
\hline & Whole E & conom & & & & & & & Private & ector & & & & & & \\
\hline & (1) & & (2) & & (3) & & (4) & & (5) & & (6) & & (7) & & (8) & \\
\hline & Raw & & $\mathrm{HC}$ & & Controls & & WP FE & & Raw & & $\mathrm{HC}$ & & Controls & & WP FE & \\
\hline Any & & & & & & & & & & & & & & & & \\
\hline Pay & 0.36 & $* * *$ & 0.29 & $* * *$ & 0.15 & $* * *$ & 0.10 & $* * *$ & 0.44 & $* * *$ & 0.33 & $* * *$ & 0.18 & $* * *$ & 0.11 & $* * *$ \\
\hline & (10.47) & & (11.16) & & (8.91) & & (6.37) & & (12.13) & & (12.09) & & (9.96) & & (6.78) & \\
\hline r2 & 0.06 & & 0.24 & & 0.58 & & 0.70 & & 0.09 & & 0.27 & & 0.61 & & 0.70 & \\
\hline $\mathrm{N}$ & 16751 & & 16751 & & 16412 & & 16412 & & 10329 & & 10329 & & 10109 & & 10109 & \\
\hline
\end{tabular}

Notes: (1) The dependent variable is log hourly wages as described in the text. (2) HC=human capital controls, namely highest academic qualification ( 8 dummies), workplace tenure ( 5 dummies) and the employee's age, which is a proxy for labour market experience (6 dummies). Columns (3) and (7) incorporate all the controls referred to in the footnote to Table 2. Columns (4) and (8) contain all the individual level demographic and job characteristics plus workplace fixed effects. (3) See Table 2 for other conventions. 
Table 6: Log Hourly Pay by Gender (separate regressions)

Panel A: Whole Economy

\begin{tabular}{|c|c|c|c|c|c|c|c|c|c|c|c|c|}
\hline & $\begin{array}{l}\text { Men } \\
(1)\end{array}$ & & $(2)$ & & (3) & & $\begin{array}{l}\text { Women } \\
\text { (4) }\end{array}$ & & (5) & & (6) & \\
\hline & Raw & & Controls & & $\mathrm{FE}$ & & Raw & & Controls & & $\mathrm{FE}$ & \\
\hline Any Performance Pay & $\begin{array}{l}0.38 \\
(9.70)\end{array}$ & $* * *$ & $\begin{array}{l}0.13 \\
(6.36)\end{array}$ & $* * *$ & $\begin{array}{l}0.10 \\
(5.10)\end{array}$ & $* * *$ & $\begin{array}{l}0.25 \\
(6.14)\end{array}$ & $* * *$ & $\begin{array}{l}0.14 \\
(5.54)\end{array}$ & $* * *$ & $\begin{array}{l}0.10 \\
(3.64)\end{array}$ & $* * *$ \\
\hline r2 & 0.07 & & 0.64 & & 0.79 & & 0.02 & & 0.52 & & 0.67 & \\
\hline $\mathrm{N}$ & 7455 & & 7333 & & 7333 & & 9420 & & 9187 & & 9187 & \\
\hline \multicolumn{13}{|l|}{ Panel B: Private sector } \\
\hline Any Performance Pay & $\begin{array}{l}0.45 \\
(10.84)\end{array}$ & $* * *$ & $\begin{array}{l}0.16 \\
(7.54)\end{array}$ & $* * *$ & $\begin{array}{l}0.12 \\
(5.93)\end{array}$ & $* * *$ & $\begin{array}{l}0.34 \\
(7.93)\end{array}$ & $* * *$ & $\begin{array}{l}0.17 \\
(6.15)\end{array}$ & $* * *$ & $\begin{array}{l}0.12 \\
(4.08)\end{array}$ & $* * *$ \\
\hline$r 2$ & 0.10 & & 0.66 & & 0.80 & & 0.05 & & 0.53 & & 0.70 & \\
\hline $\mathrm{N}$ & 5211 & & 5121 & & 5121 & & 5196 & & 5055 & & 5055 & \\
\hline
\end{tabular}

Notes: (1) The dependent variable is log hourly wages described in the text. (2) Models are run separately for men and women. Panel A is for the whole economy. Panel B is confined to employees in the private sector. (3) Controls are those in Models (3) and (7) in Table 5, other than gender. Columns (3) and (6) contain all the individual level demographic and job characteristics plus workplace fixed effects. (4) See Table 2 for other conventions. 
Table 7: Log Hourly Pay: Interactions between Performance Pay and Human Capital Whole Economy:

Private sector:

\begin{tabular}{|c|c|c|c|c|c|c|}
\hline & Raw & Controls & $\mathrm{FE}$ & Raw & Controls & FE \\
\hline \multirow[t]{2}{*}{ Any Performance Pay } & 0.082 & 0.003 & -0.04 & 0.058 & -0.021 & -0.049 \\
\hline & 0.91 & 0.05 & -0.74 & 0.61 & -0.34 & -0.88 \\
\hline \multirow[t]{2}{*}{ Highest qualification } & $0.099 * * *$ & $0.039 * * *$ & $0.032 * * *$ & $0.096 * * *$ & $0.037^{* * *}$ & $0.030 * * *$ \\
\hline & 25.8 & 12.29 & 10.43 & 20.23 & 9.49 & 7.47 \\
\hline \multirow[t]{2}{*}{ PP*qualifications } & $0.033 * * *$ & $0.018 * *$ & 0.008 & $0.038 * * *$ & $0.022 * *$ & 0.01 \\
\hline & 3.75 & 2.77 & 1.39 & 4.02 & 3.17 & 1.65 \\
\hline \multirow[t]{2}{*}{ Age } & $0.073 * * *$ & $0.045^{* * *}$ & $0.037 * * *$ & $0.079 * * *$ & $0.050 * * *$ & $0.048^{* * *}$ \\
\hline & 11.39 & 8.54 & 6.96 & 10.39 & 7.8 & 7.38 \\
\hline \multirow[t]{2}{*}{ PP*age } & $0.041^{*}$ & $0.025^{*}$ & $0.025^{*}$ & $0.043^{*}$ & 0.024 & 0.021 \\
\hline & 2.48 & 2.2 & 2.36 & 2.42 & 1.92 & 1.89 \\
\hline \multirow[t]{2}{*}{ Tenure } & $0.070 * * *$ & $0.038 * * *$ & $0.040 * * *$ & $0.065^{* * *}$ & $0.033 * * *$ & $0.034 * * *$ \\
\hline & 11.22 & 8.2 & 9.13 & 8.62 & 5.69 & 6.42 \\
\hline \multirow[t]{2}{*}{ PP*tenure } & -0.018 & -0.003 & 0.005 & -0.005 & 0.01 & 0.015 \\
\hline & $(-1.12)$ & $(-0.25)$ & 0.51 & $(-0.31)$ & -0.85 & 1.3 \\
\hline r2 & 0.216 & 0.57 & 0.482 & 0.248 & 0.597 & 0.487 \\
\hline$N$ & 16751 & 16412 & 16412 & 10329 & 10109 & 10109 \\
\hline
\end{tabular}

Notes: (1) Models are similar to those in Table 5 but interact performance pay (PP) with human capital variables entered as linear terms. 
Figure 1: Correlation between Log Hourly Pay Based on WERS Mid-Points (x- axis) and on ASHE Mid-Points (y-axis)

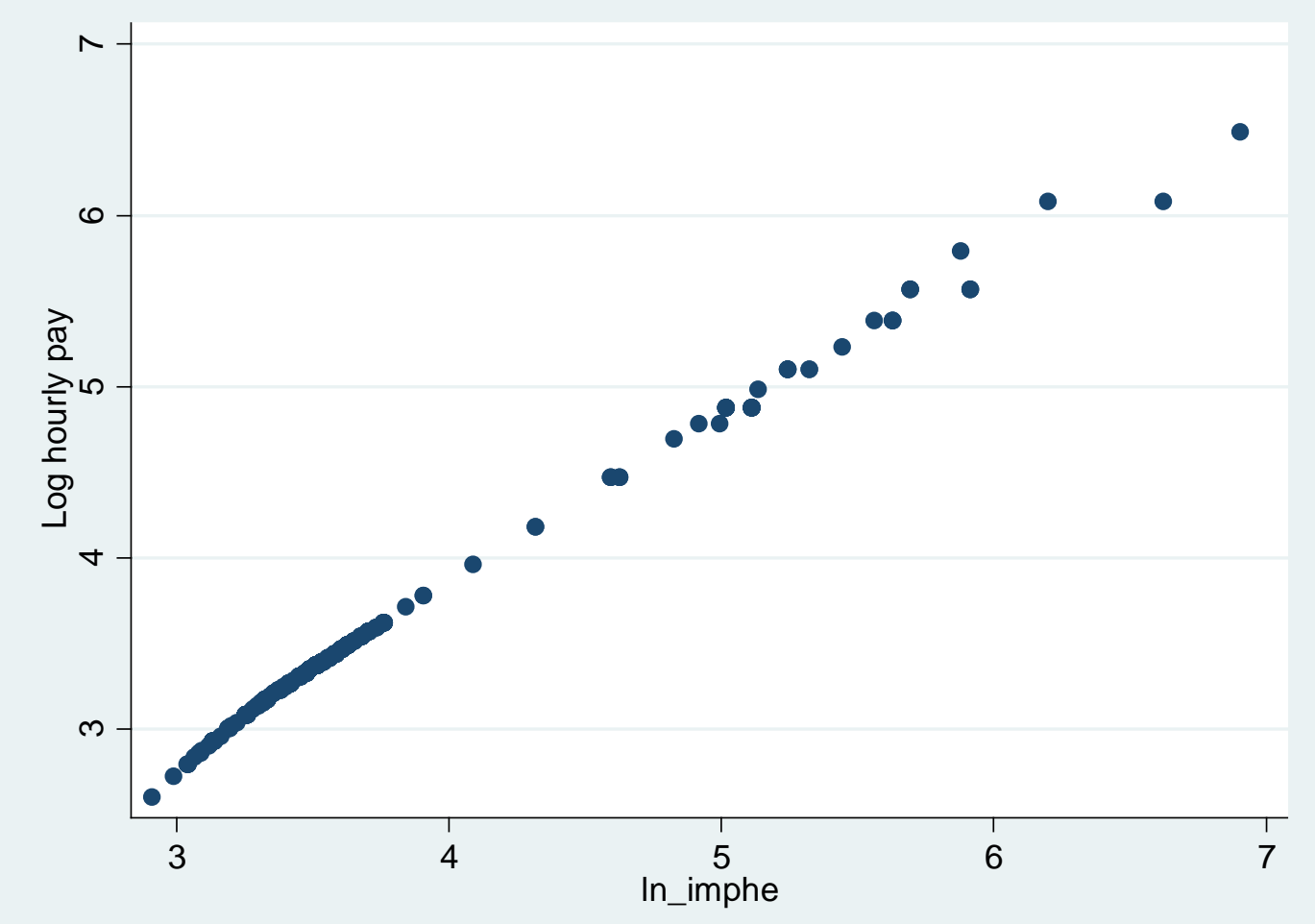


Figure 2. Performance Pay Wage Gap WERS Whole Economy: 2011

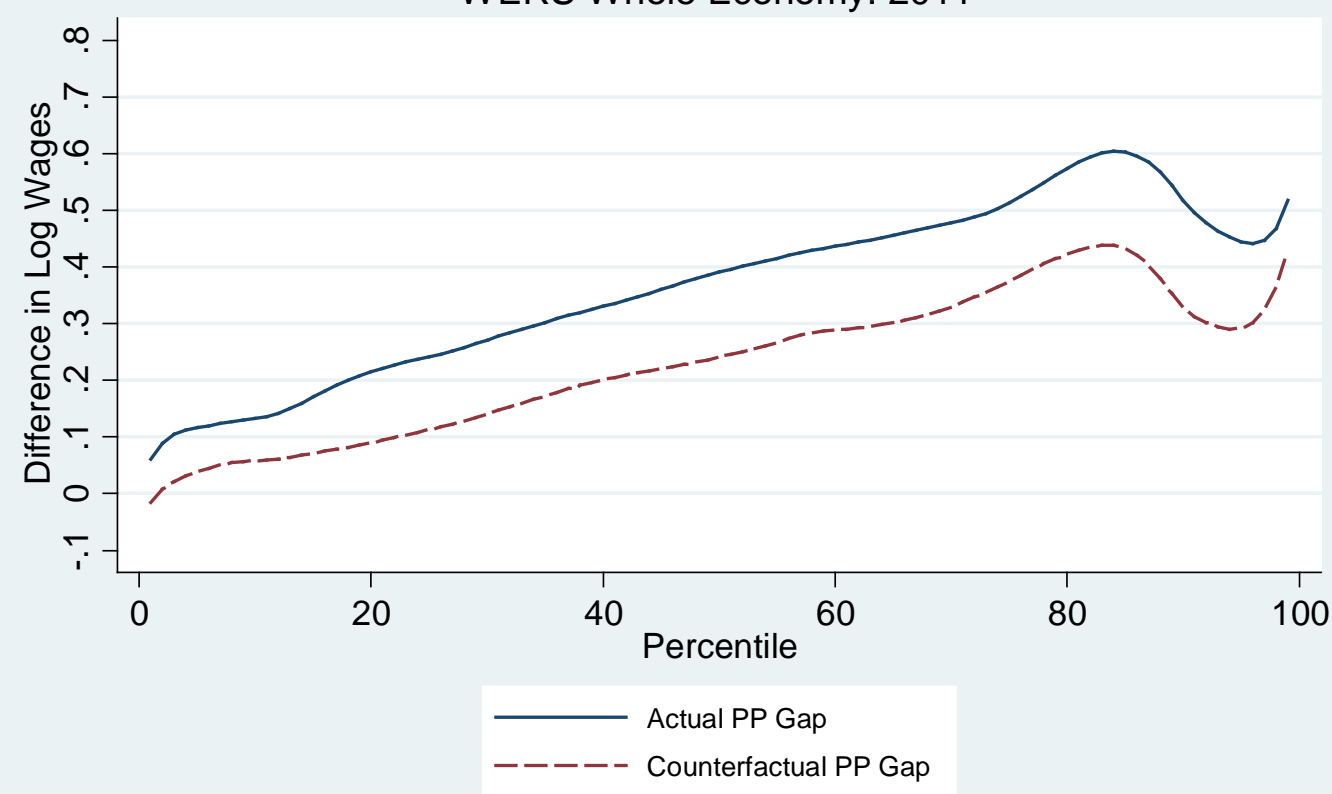

Smoothed by Locally Weighted Regression

Figure 3. Performance Pay Wage Gap

WERS Whole Economy covered only

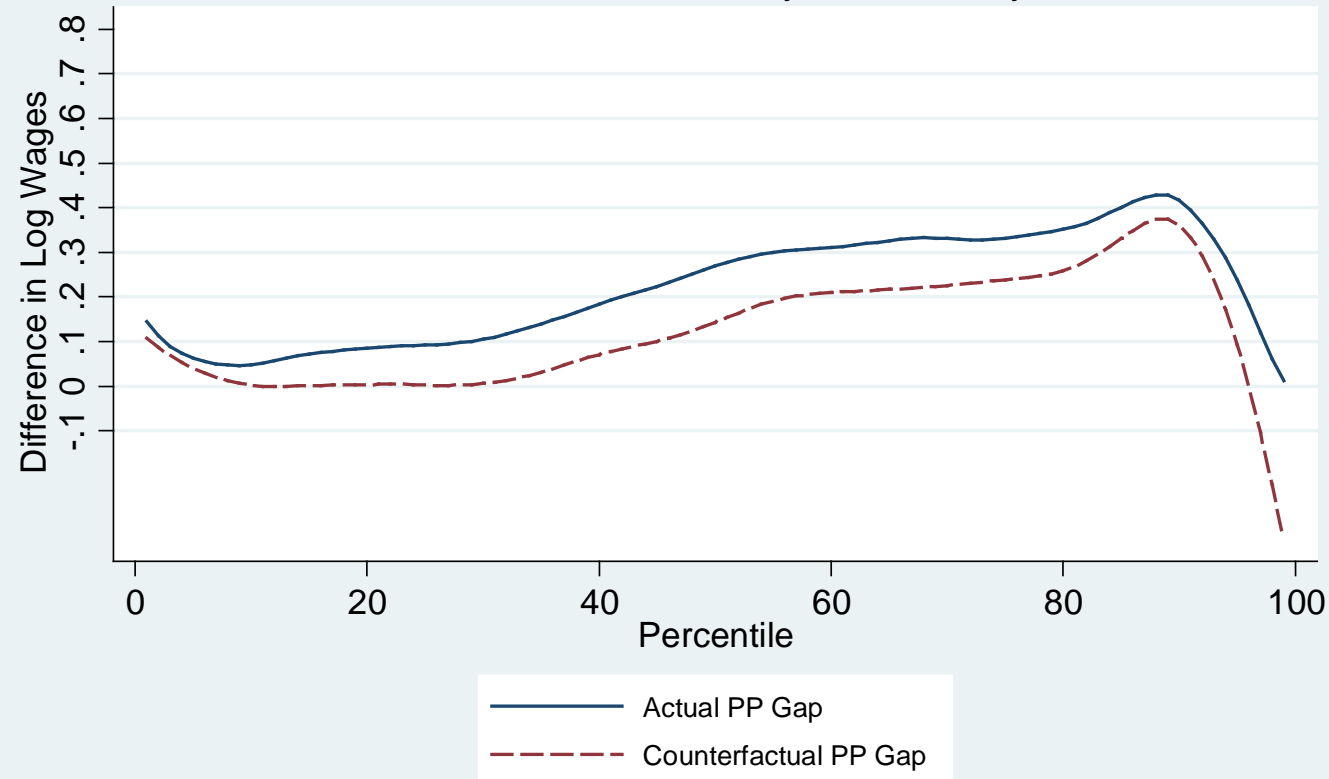

Smoothed by Locally Weighted Regression 
Figure 4. Performance Pay Wage Gap

WERS Whole Economy uncovered only

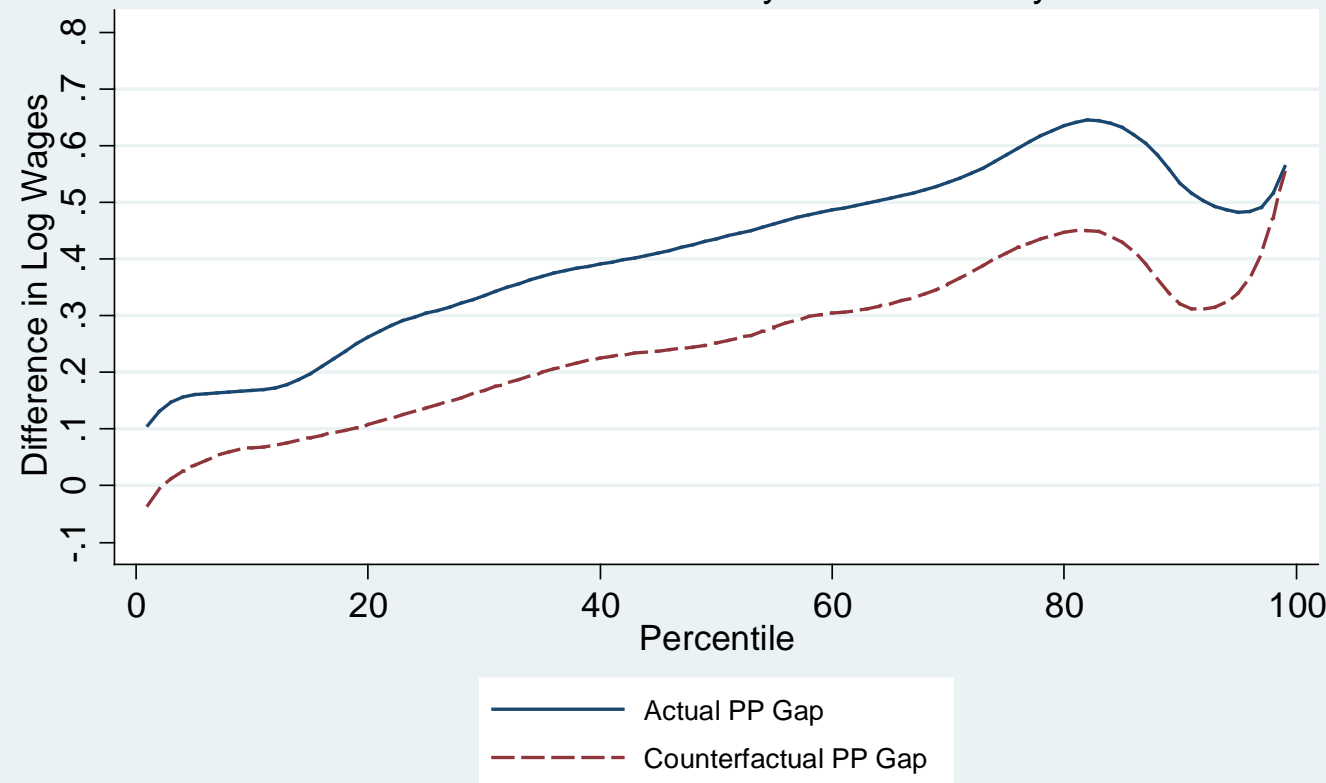

Smoothed by Locally Weighted Regression 